\title{
Choroid Plexus Papilloma
}

National Cancer Institute

\section{Source}

National Cancer Institute. Choroid Plexus Papilloma. NCI Thesaurus. Code C3698.

A benign, slow growing tumor which may cause symptoms by blocking cerebrospinal fluid pathways. It is characterized by the presence of delicate fibrovascular connective tissue fronds covered by a single layer of epithelial cells. Mitotic activity is extremely low.

Surgical resection is usually curative. (Adapted from WHO) 